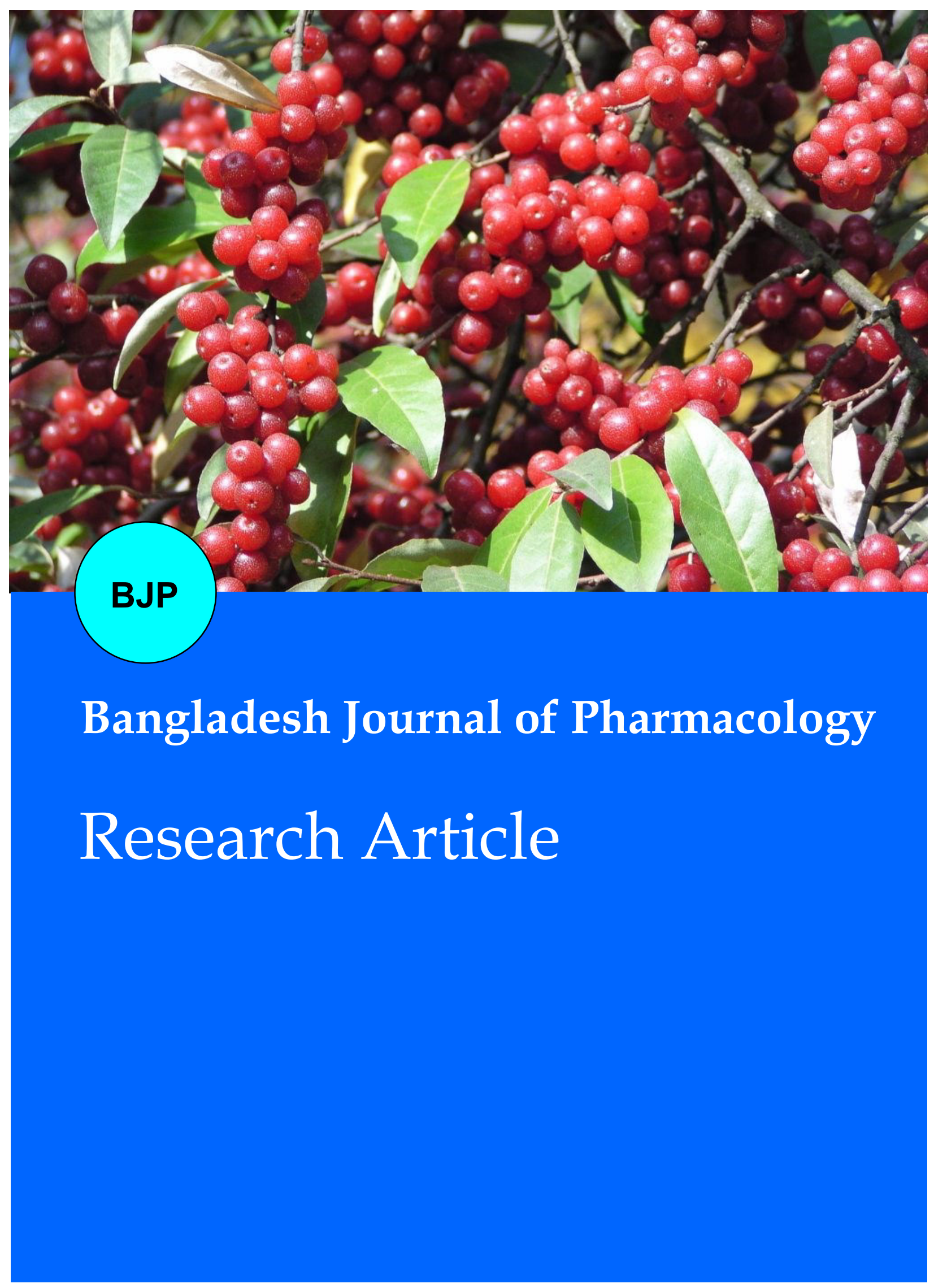


Abstracted/indexed in Academic Search Complete, Asia Journals Online, Bangladesh Journals Online, Biological Abstracts, BIOSIS Previews, CAB Abstracts, Current Abstracts, Directory of Open Access Journals, EMBASE/Excerpta Medica, Google Scholar, HINARI (WHO), International

\title{
Calcium entry blocking activity of the Elaeagnus umbellata fruit extract explains its use in diarrhea and gut spasm
}

\author{
Nayyab Rafique, Taous Khan and Abdul Jabbar Shah
}

Department of Pharmacy, COMSATS Institute of Information Technology, University Road, Abbottabad 22060, KPK, Pakistan.

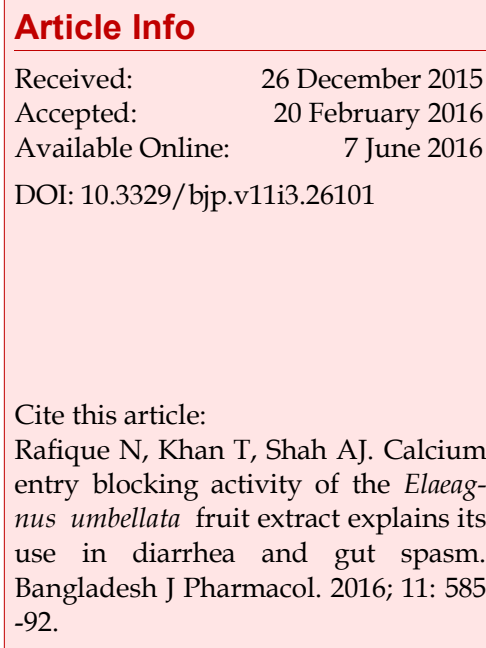

\section{Abstract}

This study was aimed to explore the pharmacological basis of potential medicinal use of Elaeagnus umbellata in gut disorders. Crude extract of E. umbellata, which was found positive for flavonoids, terpenoids and tannins, provided 9.9-71.9\% protection in castor oil-induced diarrhea in mice, like verapamil. In isolated rabbit jejunum preparations, crude extract caused inhibition of spontaneous and high $\mathrm{K}^{+}$-induced contractions, with respective $\mathrm{EC}_{50}$ values of 0.3 (0.1-0.5) and $0.5 \mathrm{mg} / \mathrm{mL}$, suggesting $\mathrm{Ca}^{2+}$ channel blockade (CCB). Pretreatment of tissue with crude extract $(0.1-1 \mathrm{mg} / \mathrm{mL})$ caused a rightward shift in $\mathrm{Ca}^{2+}$ concentration-response curves. With the exception of aqueous fraction, $n$-hexane, chloroform and ethyl acetate inhibited spontaneous and high $\mathrm{K}^{+}$-induced contractions and displaced rightward $\mathrm{Ca}^{2+}$ concentrationresponse curves. Extract was found safe up to $10 \mathrm{mg} / \mathrm{kg}$ in mice. Our data shows that anti-diarrheal effect of crude extract of E. umbellate is due to CCBmediated spasmolytic effect, concentrated in the ethyl acetate fraction and suggests its medicinal importance in diarrhea and spasm.

\section{Introduction}

Elaeagnus umbellata Thunb (Autum olive, family; Elaeagnaceae) is a wild shrub abundant in northern areas of Pakistan (Hussain, 2011). Locally it's known as "Kankoli". Fruits, flowers and seeds of E. umbellata are used for medicinal purposes (Ahmad et al., 2005). Medicinal uses have been reported for various species of Elaeagnaceae; fruit of E. phillipinus have been used in the treatment of amoebic dysentery, flatulence, nausea and vomiting (Mohammed et al., 2006). Fruits of E. aungustifolia found useful in diarrhea and dysentery (Mohammed et al., 2006). In Chinese traditional medicine, fruits of E. multiflora are useful in itch, diarrhea, foul sours, cough and cancer (Lee et al., 2007). However, medicinal reputation of E. umbellata in hyperactive gut disorders, such as diarrhea and spasm is lacking.
The plant contains different phytochemicals, such as vitamins (A, C and E), flavonoids, essential fatty acids, lycopene, $\beta$-carotene, lutein, phytofluene, and phytoene (Fordham et al., 2001). $\beta$-Carotenes are effective in cancers. Lutein is an anti-oxidant and is as smooth muscle relaxant (Johnson et al., 2000). Phytoenes are antioxidant and anti-inflammatory (Khachik et al., 2002).

E. umbellata has not been explored pharmacologically in the past. However, few studies are available on its fruit extract such as antibacterial, against Staphylococci and Escherichia coli and anti-oxidant. E. umbellate was ignored in the past as a potential for pharmacological investigation.

The present study aimed at exploring the underlying pharmacological mechanism of the fruit extract of $E$. umbellata. 


\section{Materials and Methods}

\section{Plant materials}

Fresh fruits of E. umbellata $(6-7 \mathrm{~kg})$ were collected from Sherwan, Abbottabad, Pakistan in the month of July, 2013 and was authenticated by Dr. Ghulam Mujtaba Shah, Department of Botany, Government Postgraduate College No. 1, Abbottabad. A voucher specimen (Eu-F07-13) was deposited at herbarium located in the Research Lab of Pharmacology and Pharmacognosy, Department of Pharmacy, COMSATS Institute of Information Technology, Abbottabad, Pakistan.

\section{Preparation of crude extract and fractionation}

Extraction and fractionation was carried out as described previously (Williamsons et al., 1996). About 5 $\mathrm{kg}$ of fresh fruit was soaked in methanol at room temperature $\left(23-25^{\circ} \mathrm{C}\right)$ for 15 days with occasional shaking. It was filtered through a muslin cloth and then through a Whatman qualitative Grade 1 filter paper. This procedure was repeated twice and the combined filtrates were evaporated on rotary evaporator under reduced pressure to a thick, semi-solid pasty mass of dark brown color; i.e. the crude extract, yielding approximately $16.8 \%$. The crude extract was solubilized in $10 \%$ Tween 80 . Fractionation was carried out, using solvents of increasing polarity. The extract was dissolved in distilled water, $n$-hexane was added to it and shaken vigorously in a separating funnel. The $n$ hexane layer (upper) was collected and evaporated on rotary evaporator to give the $n$-hexane fraction (yielding about $13 \%$ ). The lower layer was taken in a separating funnel, chloroform was added. The chloroform layer (lower) was collected and evaporated on rotary evaporator to obtain the chloroform fraction (yielding about $21 \%$ ). The other layer (upper) was again taken into a separating funnel, ethyl acetate was added into it, separated and was also evaporated in rotary evaporator to give the ethyl acetate fraction (yielding about $24 \%$ ). The remaining lower layer was collected and evaporated to yield the aqueous fraction (yielding about $42 \%$ ).

\section{Drugs and standards}

The following reference chemicals were obtained from the sources specified: Castor oil (Karachi Chemical Laboratories, Pakistan), acetylcholine chloride, potassium chloride, $\mathrm{Ca}^{2+}$ chloride and verapamil hydrochloride (Sigma Chemical Company, USA). All chemicals used were of the highest purity grade. Stock solutions of all the chemicals were made in distilled water and the dilutions were made fresh on the day of experiment.

\section{Animals}

Balbc mice (20-25 g) and local rabbits (1.5-2 kg) used in the study were bred and housed in the animal house of CIIT Abbottabad under controlled environment (23-25 C). Animals were given tap water ad libitum and a standard diet.

\section{Preliminary phytochemical analysis}

The crude extract of E. umbellata was screened for the presence of saponins, flavonoids, tannins, phenol, terpenes, terpenoids and alkaloids using the methods described by Edeoga et al. (2005).

\section{Acute toxicity test}

The test was performed as described formerly (Gilani et al., 2005b). Groups containing five mice each were made. Group I acted as negative control was administered normal saline $(10 \mathrm{~mL} / \mathrm{kg})$. Groups II-IV were treated with crude extract applied in incrementing doses $(3,5$, and $10 \mathrm{~g} / \mathrm{kg}$ ) and were observed regularly for time period of 24 hours for lethality or toxic effects as flatness, gastrointestinal cramps and diarrhea.

\section{Castor oil-induced diarrhea}

Previously described methods were modified for the determination of in vivo anti-diarrheal activity of the extract (Awouters et al., 1978; Shah et al., 2010a). Balbc albino mice after being starved for 18 hours were confined in nine groups with five mice in each individual cage, with their bases covered with blotting sheets. Group I, received normal saline $(10 \mathrm{~mL} / \mathrm{kg}, \mathrm{p} . \mathrm{o})$ acted as vehicle control. Group II was administered castor oil. Groups III-VI were treated with four doses (3, 10,30 and $100 \mathrm{mg} / \mathrm{kg}$ ), selected on trial basis, of the crude extract of E. umbellata. Three doses of verapamil $(1,3$ and $10 \mathrm{mg} / \mathrm{kg}$ ) were given to mice placed in groups 7-9. All of the doses were administered orally through an intragastric feeding tube. Castor oil $(10 \mathrm{~mL} /$ $\mathrm{kg}$ ) was administered, accept the saline treated group after one hour following the above treatments. All the groups were kept under observation for 4 hours after castor oil administration for defecation pattern. Percentage protection against the diarrhea induced by castor oil was calculated by comparing wet and dry fecal count in each cage.

\section{Determination of mechanism of anti-diarrheal action}

\section{Isolated tissue preparations (Video Clip)}

The isolated tissue experiments were carried out as described previously (Shah et al., 2010b). The animals had free access to water but were fasted for 24 hours before the experiment. The animals were killed by cervical dislocation, the abdomen was cut open and the jejunal portion isolated out. Preparations $2 \mathrm{~cm}$ long were mounted in $10 \mathrm{~mL}$ tissue baths containing Tyrode's solution maintained at $37^{\circ} \mathrm{C}$ and aerated with a mixture of $5 \%$ carbon dioxide in oxygen (carbogen). The composition of Tyrode's solution, in $\mathrm{mM}$, was: $\mathrm{KCl}$ 2.7, $\mathrm{NaCl}$ 136.9, $\mathrm{MgCl}_{2}$ 1.1, $\mathrm{NaHCO}_{3} 11.9$ and $\mathrm{NaH}_{2} \mathrm{PO}_{4}$ 0.4 , glucose 5.6 and $\mathrm{CaCl}_{2} 1.8$ ( $\mathrm{pH} 7.4$ ). A preload of $1 \mathrm{~g}$ was applied and the tissues kept undis-turbed for an equilibrium period of $30 \mathrm{~min}$ after which control responses to a submaximal dose of acetylcholine $(0.3$ $\mathrm{mM}$ ) were obtained and the tissue presumed stable 
only after the reproducibility of the said responses. Under these experimental conditions, rabbit jejunum exhibits spontaneous rhythmic contractions, allowing the testing of the relaxant (spasmolytic) activity directly without the use of an agonist (Gilani and Aftab, 1992).

\section{Determination of calcium antagonist activity}

To assess whether the spasmolytic activity of the test substances was mediated through $\mathrm{Ca}^{2+}$ channel blockade, a high concentration of $\mathrm{K}^{+}(80 \mathrm{mM})$, was used to depolarize the preparations and produced a sustained contraction. Plant extract and standard were then added in a cumulative fashion to obtain concentrationdependent inhibitory responses (van Rossum, 1963). The relaxation of intestinal preparations to plant extract and standard, precontracted with high $\mathrm{K}^{+}(80 \mathrm{mM})$, was expressed as the percent of the control precontraction. To confirm the $\mathrm{Ca}^{2+}$ antagonist activity of test substances, the tissue was allowed to stabilize in normal Tyrode's solution, which was then replaced with $\mathrm{Ca}^{2+}$ - free Tyrode's solution containing EDTA (0.1 $\mathrm{mM}$ ) for $30 \mathrm{~min}$ in order to remove $\mathrm{Ca}^{++}$from the tissues. This solution was further replaced with $\mathrm{K}^{+}$-rich and $\mathrm{Ca}^{++}$-free Tyrode's solution, having the following composition: $\mathrm{KCl} 50, \mathrm{NaCl} 91.04, \mathrm{MgCl}_{2} 1.05, \mathrm{NaHCO}_{3}$ 11.90, $\mathrm{NaH}_{2} \mathrm{PO}_{4}$ 0.42, glucose 5.55 and EDTA $0.1 \mathrm{mM}$. Following an incubation period of $30 \mathrm{~min}$, control concentration-response curves of $\mathrm{CaCl}_{2}$ were obtained. When the control concentration-response curves of $\mathrm{CaCl}_{2}$ were found super imposable (usually after two cycles), the tissue was pretreated with the plant extract for $60 \mathrm{~min}$ to test the possible $\mathrm{Ca}^{2+}$ channel blocking (CCB) effect. The concentration-response curves of $\mathrm{CaCl}_{2}$ were reproduced in the presence of different concentrations of the extract and standard.

\section{Statistics}

All the data expressed are mean \pm standard error of the mean (SEM), and the median effective concentrations (EC 50 values) are given with $95 \%$ confidence intervals (CI). The statistical parameter applied is the student's $t$ test with $p<0.05$ noted as significantly different (Graph pad prism).

\section{Results \\ Effect on castor oil-induced diarrhea}

Crude extract from the fruit of E. umbellata inhibited significantly $(p<0.05)$ the frequency of defecation as well as wetting of feces compared with the untreated group, similar to verapamil. Both crude extract and verapamil reduced greatly the wetness of the fecal droppings and provided around 9.6-71.9\% and 34.1$80.9 \%$ protection, respectively (Table I).

\section{Effect on isolated rabbit jejunum preparation}

Crude extract of E. umbellata inhibited isolated rabbit jejunum spontaneous contractions, similar to that observed with verapamil (Figure 1). This inhibition was concentration-dependent and maximum inhibition occurred at $5 \mathrm{mg} / \mathrm{mL}$, with $\mathrm{EC}_{50}$ value of $0.3 \mathrm{mg} / \mathrm{mL}$ (0.1-0.5). Verapamil also inhibited spontaneous contractions (Figure 1). Crude extract caused a concentrationdependent inhibition of high $\mathrm{K}^{+}$-induced sustained contraction with $\mathrm{EC}_{50}$ value of $3.4 \mathrm{mg} / \mathrm{mL}(2.6-4.2 ; \mathrm{n}=5)$ (Figure 2). Pretreatment of the jejunal tissues with crude exctract $(3-10 \mathrm{mg} / \mathrm{mL})$ caused a rightward shift in the $\mathrm{CaCl}_{2}$ concentration-response curves. Verapamil also inhibited high $\mathrm{K}^{+}$-induced contractions and shifted

\section{Table I}

Effect of Elaeagnus umbellata methanolic crude extract of the fruit on castor oil-induced diarrhea in mice

\begin{tabular}{|lrccc|}
\hline Group & Dose & Total number of feces in 4 hours & Total number of wet feces in 4 hours & Protection (\%) \\
\hline Control (saline) & $10 \mathrm{~mL} / \mathrm{kg}$ & $4.8 \pm 0.4$ & $4.0 \pm 4.0$ & $9.6 \pm 4.0$ \\
Castor oil & $10 \mathrm{~mL} / \mathrm{kg}$ & $10 \pm 0.6$ & $98.2 \pm 2.3$ & $2.6 \pm 2.3$ \\
+ crude extract & $3 \mathrm{mg} / \mathrm{kg}$ & $4.0 \pm 0.5$ & $90.0 \pm 6.6$ & $9.98 \pm 6.6$ \\
+ crude extract & $10 \mathrm{mg} / \mathrm{kg}$ & $5.0 \pm 2.5$ & $82.7 \pm 7.3$ & $17.2 \pm 7.3$ \\
+ crude extract & $30 \mathrm{mg} / \mathrm{kg}$ & $5.8 \pm 0.5$ & $65.8 \pm 3.7$ & $40.7 \pm 3.7$ \\
+ crude extract & $100 \mathrm{mg} / \mathrm{kg}$ & $8.4 \pm 0.2$ & $28.6 \pm 2.9$ & $71.9 \pm 3.0$ \\
+ Verapamil & $1 \mathrm{mg} / \mathrm{kg}$ & $5.8 \pm 0.5$ & $65.8 \pm 3.7$ & $34.1 \pm 3.7$ \\
+ Verapamil & $3 \mathrm{mg} / \mathrm{kg}$ & $7.2 \pm 0.3$ & $43.4 \pm 6.0$ & $56.5 \pm 6.0$ \\
+ Verapamil & $10 \mathrm{mg} / \mathrm{kg}$ & $8.4 \pm 0.2$ & $28.6 \pm 2.9$ & $80.9 \pm 2.9$ \\
\hline
\end{tabular}

Data are Mean \pm SEM; $n=5$ in each group; ${ }^{\mathrm{p}} \mathrm{p}<0.05,{ }^{\mathrm{b}} \mathrm{p}<0.01$ and ${ }^{\mathrm{c}} \mathrm{p}<0.001$ vs control, Student's t-test 


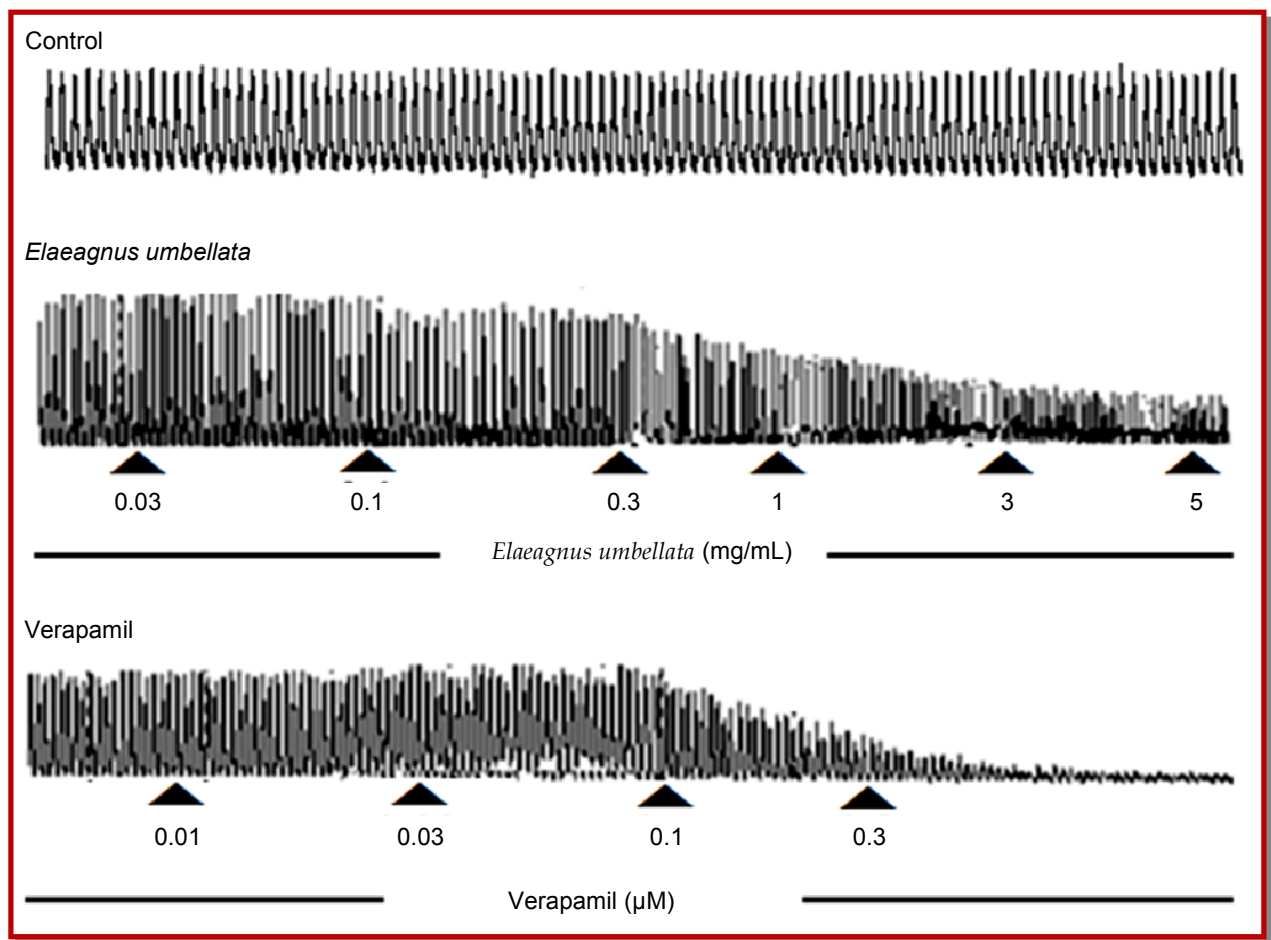

Figure 1: Typical tracing showing spasmolytic effect of Elaeagnus umbellata crude extract and verapamil in isolated rabbit jejunum

rightward $\mathrm{CaCl}_{2}$ concentration-response curves.

Among the fractions tested; the $n$-hexane, chloroform and ethylacetate inhibited spontaneous contractions, the later fraction was most potent with $\mathrm{EC}_{50}$ value $0.2 \mathrm{mg} / \mathrm{mL}(0.1-0.3) \quad$ (Figure 3). n-hexane, chloroform and ethyl acetate inhibited high $\mathrm{K}^{+}$induced contractions. The later fraction was more potent than the parent crude extract and fractions, with $\mathrm{EC}_{50}$ value of $0.8 \mathrm{mg} / \mathrm{mL}$ (0.5-1.3). Pretreatment of the jejunal preparations with extract of $n$-hexane (3-10 mg/mL), chloroform (1-5 mg/mL) and ethyl acetate $(0.1-1 \mathrm{mg} / \mathrm{mL})$ caused a right ward shift in the $\mathrm{Ca}^{2+}$ concentration-response curves. Interestingly, the aqueous fraction did not affect spontaneous and high $\mathrm{K}^{+}$-induced contractions.

\section{Discussion}

In castor oil-induced diarrheal model in mice, crude extract from the fruit of E. umbellata inhibited significantly $(p<0.05)$ the frequency of defecation as well as wetting of feces compared with the untreated group, similar to verapamil (Karaki and Weiss, 1983; Godfraind et al., 1986). Both crude extract and verapamil reduced greatly the wetness of the fecal droppings and provided around $9.6-71.9 \%$ and $34.1-80.9 \%$ protection. The induction of diarrhea by castor oil results from the action of ricinoleic acid, which is formed as a result of the hydrolysis of the oil resulting changes in the transport of water and electrolytes in the intestine and leads to a hypersecretory response and generation of a giant contraction of the intestine (Shah et al., 2011). This provides a base to understand that a potential antidiarrheal agent may exhibit its anti-diarrheal effect by inhibiting gut motility (spasmolytic) and/or electrolyte outflux, the latter is evident in the form of diarrheal droppings. The protective effect of the crude extract of E. umbellata against the castor oil-induced diarrhea in mice, similar to verapamil, suggests that it might exert an inhibitory effect on intestinal smooth muscle contraction (intestinsl motility) and or secretion. To see its possible inhibitory effect on gut motility, the crude extract was further studied in isolated rabbit jejunum.

Spontaneously beating isolated rabbit jejunum preparations are usually used to test possible antispasmodic effect of test substance because rabbit jejunum contracts spontaneously and does not require agonists to induced rhythmic contractions (Gilani and Aftab, 1992). Crude extract suppressed rabbit jejunum spontaneous contractions in a concentration-dependent manner, similar to that caused by verapamil.

The contraction of smooth muscle preparations, including rabbit jejunum, is dependent upon increase in the cytosolic free $\mathrm{Ca}^{2+}$ concentration, which activates the contractile elements and ensure contraction (Karaki and Weiss, 1983). The increase in intracellular $\mathrm{Ca}^{2+}$ occurs either via influx through voltage-dependent $\mathrm{Ca}^{2+}$ channels (VDCs) or its release from intracellular stores in the sarcoplasmic reticulum. Periodic depolarization and repolarization regulates the spontaneous movements of the intestine and at the height of depolarization, the action potential appears as a rapid influx of 

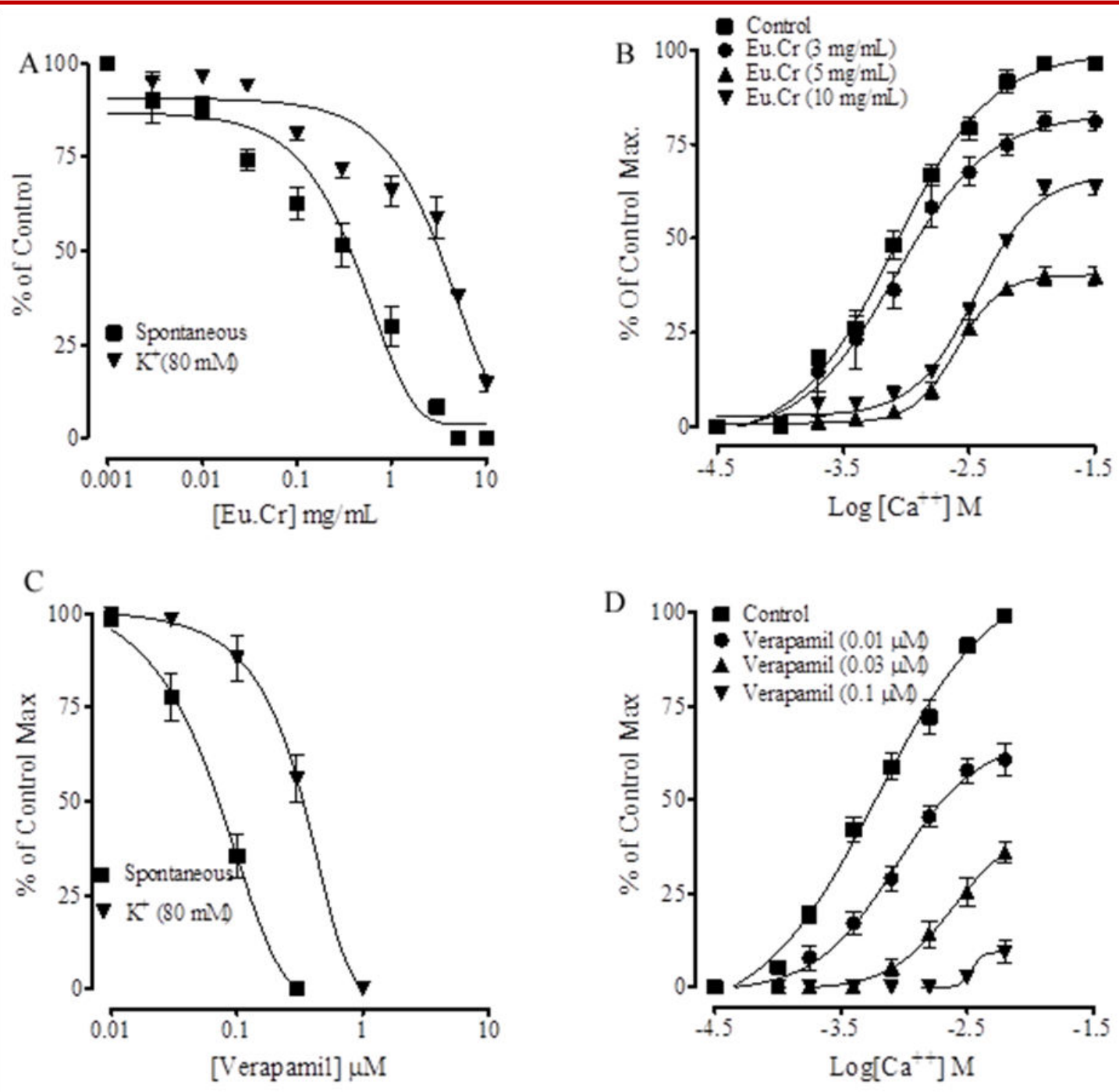

Figure 2: Concentration-response curves of the crude extract of (A) Elaeagnus umbellata (Eu.Cr) and (C) verapamil on spontaneous and high $\mathrm{K}^{+}(80 \mathrm{mM})$-induced contractions. Figure $\mathrm{B}$ and $\mathrm{D}$ show effect on $\mathrm{CaCl}_{2}$ concentration-response curves in the absence and presence of different concentrations of the Eu.Cr and verapamil, respectively, in isolated rabbit jejunum preparations. Values shown are mean \pm SEM $(n=6-7)$

$\mathrm{Ca}^{2+}$ via VDCs (Brading, 1981). Thus, the inhibitory effect of the crude extract on isolated rabbit jejunum spontaneous contraction seems due to a possibly interference with $\mathrm{Ca}^{2+}$ influx through VDCs. We have previously observed that the spasmolytic constituents present in different medicinal plants mediate their effect through an inhibitor effect on $\mathrm{Ca}^{2+}$ movement (Gilani et al., 2005a, 2005b). To see whether the spasmolytic effect of the crude extract is mediated through an inhibitor effect on $\mathrm{Ca}^{++}$ influx through VDCs, a high concentration of $\mathrm{K}^{+}(80$ $\mathrm{mM}$ ) was intro-duced to depolarize the tissue. This depolarization produced sustained contraction of the jejunal prepara-tion and allowed to see the effect of the crude extract and verapamil. Crude extract caused a concentration-dependent inhibition of high $\mathrm{K}^{+}$-induced sustained contraction in the isolated rabbit jejunal preparation, similar to verapamil.
This suggests that the spasmolytic effect of crude extract is, mediated through its inhibitory effect on $\mathrm{Ca}^{2+}$ influx. Thus, the inhibi-tion of high $\mathrm{K}^{+-}$ induced contractions of rabbit jejunum by crude extract may reflect the restricted $\mathrm{Ca}^{++}$entry via VDCs. This hypothesis was further strengthened when pre-treatment of the jejunal tissues with crude extract caused a rightward shift in the $\mathrm{CaCl}_{2}$ concentration-response curves, similar to verapamil.

Further studies were carried out on the fractions to see, if any shift of the activity to any of the fractions. We obtained 4 fractions; n-hexane, chloroform, ethyl acetate and aqueous. When tested in the isolated rabbit jejnum preparations, $n$-hexane, chloroform and ethyl acetate fractions inhibited spontaneous and high $\mathrm{K}^{+}$ induced contractions. Ethyl acetate fraction was the 

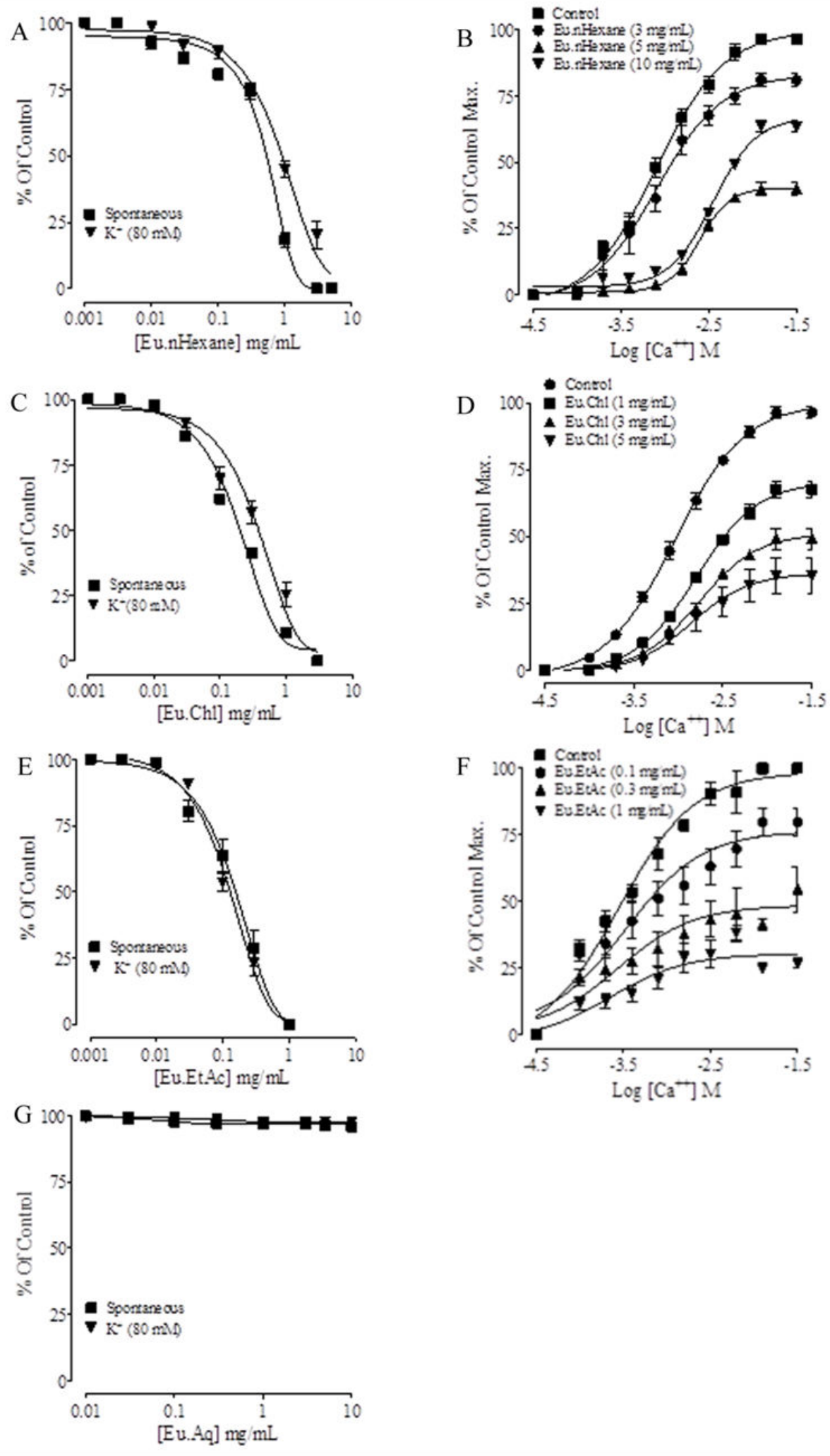

Figure 3: Concentration-response curves of $n$-hexane (Eu. $n$-hexane) (A) chloroform (Eu. Chl) (C) ethyle acetate (Eu. Et AC) (E) and aqueous $(\mathrm{Eu} . \mathrm{Aq})(\mathrm{G})$ fractions on spontaneous and high $\mathrm{K}^{+}(80 \mathrm{mM})$-induced contractions. Figure $\mathrm{B}, \mathrm{D}$ and $\mathrm{F}$ show effect on $\mathrm{CaCl}_{2}$ concentration-response curves in the absence and presence of different concentrations of the Eu. $n$-hexane, Eu. Chl, Eu. EtAc, Eu. Aq, respectively, in isolated rabbit jejunum preparations. Values shown are mean \pm SEM $(n=6-7)$ 
most potent among the fractions tested, this data suggest that the spasmolytic constituents are more concentrated in this particular fraction. Pretreatment of the jejunal preparations with these fractions caused a right ward shift in the $\mathrm{Ca}^{2+}$ concentration response curves, indicating that these fractions possess CCB activity; Ethyl acetate being the most potent. Interestingly, the aqueous fraction did not affect spontaneous and high $\mathrm{K}^{+}$-induced contraction. This is not surprising as most of the sugar kind of constituents is concentrating in such fraction, which lacks effect.

These data indicate that crude extract and its organic fractions with the exception of aqueous fraction possess spasmolytic effect, which is possibly mediated through $\mathrm{Ca}^{2+}$ channel blockade and the activity is more concentrated in the ethyl acetate fraction than the crude extract and other fractions. The CCB-mediated spasmolytic effect may be responsible, as a mechanism for the antidiarrheal effect of the extract. Preliminary phytochemical analysis of the crude extract indicated presence of flavonoids, terpenoids and tannins. Plant-derived flavonoids, terpenes and tannins have smooth muscle relaxant effects. The smooth muscle relaxant effect of these natural products is mediated through various mechanisms including CCB (Zhu et al., 1997; de Alencar Cunha et al., 2003; Zhu et al., 2005) as CCBs are considered useful in diarrhea and gut spasms (Brunton, 1996). Kaurenoic acid, a terpene isolated from Copaifera langsdorffii possesses $\mathrm{Ca}^{2+}$ entry blockade-mediated smooth muscle relaxant effect (de Alencar Cunha et al., 2003). We believe that terpenes/terpenoids present in the extract of E. umbellata might be the active constituents that mediate intestinal smooth muscle relaxation through inhibitory effect on VDCs.

\section{Conclusion}

E. uctmbellata crude extract possesses CCB-mediated smooth muscle relaxant effect that is concentrated more in the ethylacetate fraction. The active constituents might be terpenoids that could possibly explain the antidirrheal and spasmolytic effects of the extract and this finding provides a possible pharmacological base to its potential medicinal use in diarrhea and gut spasms. Further studies will be worthwhile to explore its flavonoids, terpenoids and tannins and molecular nature of spasmolytic and antidiarrheal effect.

\section{Ethical Issue}

Experiments performed complied with the rulings of the Institute of Laboratory Animal Resources, Commission on Life Sciences, National Research Council (National Research Council, 1996) and were approved by the Ethical Committee of CIIT, Abbottabad.

\section{Conflict of Interest}

The authors report no conflict of interest as document in HTML file.

\section{Acknowledgement}

This study was carried out from a grant to the principle investigator from the Higher Education Commission (HEC) of Pakistan. Authors are thankful for assistance of PhD students; Rahila Qayyum, Hafiz Misbah-ud-Din Qamar, Shamim Khan and Umme Salma in finalizing the manuscript.

\section{References}

Ahmad SD, Sabir MS, Juma M, Asad HS. Morphological and biochemical variations in Elaeagnus umbellata Thunb. from mountains of Pakistan. Acta Bot Croat. 2005; 64: 121-28.

Awouters F, Niemegeers CJE, Lenaerts FM, Janssen PAJ. Delay of castor oil diarrhea in rats, a new way to evaluate inhibitors of prostaglandin biosynthesis. J Pharm Pharmacol. 1978; 30: 41-45.

Brading AF. How do drugs initiate contraction in smooth muscles? Trends Pharmacol Sci. 1981; 2: 261-65.

Brunton LL. Agents affecting gastrointestinal water flux and motility; emesis and antiemetics; bile acids and pancreatic enzymes. In: Goodman and Gillman's The pharmacological basis of therapeutics. Hardman JG, Limbird LE, Molinoff PB (eds). $7^{\text {th }}$ ed. New York, McGraw Hill, 1996, pp 1771-85.

de Alencar Cunha KM, Paiva LA, Santos FA, Gramosa NV, Silveira ER and Rao VS. Smooth muscle relaxant effect of kaurenoic acid, a diterpene from Copaifera langsdorffii on rat uterus in vitro. Phytother Res. 2003; 17: 320-24.

Edeoga H, Okwu D, Mbaebie B. Phytochemical constituents of some Nigerian medicinal plants. Afr J Biotechnol. 2005; 4: 685-88.

Fordham IM, Clevidence BA, Wiley ER, Zimmerma RH. Fruit of autumn olive: A rich source of lycopene. Hort Sci. 2001; 36: 1136-37.

Gilani AH, Aftab K. Presence of acetylcholine-like substance (s) in Sesamum indicum. Arch Pharmacol Res. 1992; 15: 95-98.

Gilani AH, Bashir S, Janbaz KH, Shah AJ. Presence of cholinergic and calcium channel blocking activities explains the traditional use of Hibiscus rosasinensis in constipation and diarrhoea. J Ethnopharmacol. 2005a; 102: 289-94.

Gilani AH, Shah AJ, Ghayur MN, Majeed K. Pharmacological basis for the use of turmeric in gastrointestinal and respiratory disorders. Life Sci. 2005b; 76: 3089-105.

Godfraind T, Miller R, Wibo M. Calcium antagonism and calcium entry blockade. Pharmacol Rev. 1986; 38: 321-416.

Hussain I. Physiochemical and sensory characteristics of Elaeagnus umbellata (Thunb) fruit from Rawalakot (Azad Kashmir) Pakistan. Afr J Food Sci. 2011; 2: 151-56.

Johnson EJ, Hammond BR, Yeum KJ. Relation among serum and tissue concentrations of lutein and zeaxanthin and macular pigment density. Am J Clin Nutr. 2000; 71: 1555-62. 
Karaki H, Weiss G. Mini-review: Calcium release in smooth muscles. Life Sci. 1983; 42: 111-22.

Khachik F, Carvalho L, Bernstein PS, Muir GJ, Zhao DY, Katz NB. Chemistry, distribution, and metabolism of tomato carotenoids and their impact on human health. Exp Biol Med. 2002; 227: 845-51

Lee YS, Chang ZQ, Oh BC, Park SC, Shin SR, Kim NW. Antioxidant activity, anti-inflammatory activity, and whitening effects of extracts of Elaeagnus multiflora Thunb. J Med Food. 2007; 10: 126-33.

Mohammed FI, Al-Essa MK, Shafagoj YA, Afifi FU. Investigation of the direct effects of the alcoholic extract of Elaeagnus angustifolia L. (Elaeagnaceae) on dispersed intestinal smooth muscle cells of guinea pig. Sci Pharm. 2006; 74: 21-33.

Shah AJ, Bhulani NN, Khan SH, Gilani AH. Calcium channel blocking activity of Mentha longifolia L. explains its medicinal use in diarrhea and gut spasm. Phytother Res. 2010a; 24: 1392-97.

Shah AJ, Gowani SA, Zuberi AJ, Ghayur MN, Gilani AH. Antidiarrhoeal and spasmolytic activities of the methanolic crude extract of Alstonia scholaris L. are mediated through calcium channel blockade. Phytother Res. 2010b; 24: 28-32.

Shah AJ, Begum S, Hassan SI, Ali SN, Siddiqui BS, Gilani AH. Pharmacological basis for the medicinal use of Psidium guajava leave in hyperactive gut disorders. Bangladesh J Pharmacol. 2011; 6: 110-16.

van Rossum JM. Cumulative dose-response curves. II. Techniques for the making of dose-response curves in isolated organs and the evaluation of drug parameters. Arch Int Pharmacodyn Ther. 1963; 143: 299-330.

Williamson EM, Okpako DT, Evans FJ. Pharmacological methods in phytotherapy research. $1^{\text {st }}$ ed. Chichester, John Wiley and Sons, 1996.

Zhu M, David PJ, Greengrass PM, Bowery NE, Cai Y. Plant polyphenols: Biologically active compounds or non-selective binders to protein? Phytochemistry 1997; 44: 441-47.

Zhu F, Huang B, Hu CY. Effects of total flavonoids of Hippophae rhamnoides $\mathrm{L}$. on intracellular free calcium in cultured vascular smooth muscle cells of spontaneously hypertensive rats and Wistar-Kyoto rats. Chin J Integr Med. 2005; 11: 287-92. 


\section{Your feedback about this paper}

1. Number of times you have read this paper 0

2. Number of times you have seen the video clip 0

3. Quality of paper Click

4. Your comments

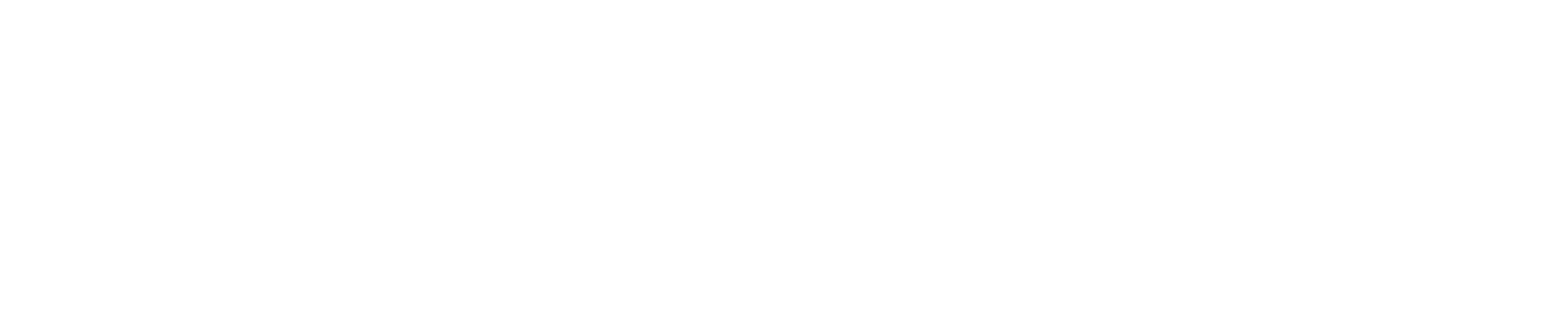

